\title{
Faktor-Faktor Motivasi yang Berpengaruh terhadap Loyalitas Anggota OSIS
}

\author{
Farida Nuraini, Burhanuddin, Djum Djum Noor Benty \\ Universitas Negeri Malang, Jl. Semarang No. 5 Malang, Jawa Timur, Indonesia \\ *Penulis korespondensi, Surel: faridanrn@gmail.com
}

Paper received: 5-7-2021; revised: 23-7-2021; accepted: 30-7-2021

\begin{abstract}
This study aims to determine motivational factors and their influence on the loyalties of intern school student council members. This study is classified as quantitative research with multivariate correlational design. The results showed that: (1) the factors of motivation namely physiological needs, security, social, respect, and self-actualization; (2) factors that encourage loyalties namely membership and duties; (3) physiological needs in the high category, security needs in the high category, social needs in the high category, the need for rewards in the medium category, and the need for self-actualization in the high category, (4) membership in the medium category, and tasks in the high category; (5) there is an influence of motivation on loyalties; simultaneously there is an influence of motivational factors on membership factors, partially the motivational factors that influence the membership factors are the need for appreciation and self-actualization needs, simultaneously there is the influence of motivational factors on task factors, partially motivational factors that affect the task factor are social needs, appreciation needs, and self-actualization needs.
\end{abstract}

Keywords: motivation; loyalties of intern school student council members

\begin{abstract}
Abstrak
Penelitian ini bertujuan untuk mengetahui faktor-faktor motivasi dan pengaruhnya terhadap loyalitas Anggota OSIS. Penelitian ini tergolong penelitian kuantitatif dengan desain correlational multivariate. Hasil penelitian menunjukkan bahwa: (1) faktor-faktor motivasi Anggota OSIS yaitu kebutuhan fisiologis, keamanan, sosial, penghargaan, dan aktualisasi diri; (2) faktor-faktor yang mendorong loyalitas yaitu keanggotaan dan tugas; (3) kebutuhan fisiologis dalam kategori tinggi, kebutuhan keamanan dalam kategori tinggi, kebutuhan sosial dalam kategori tinggi, kebutuhan penghargaan dalam kategori sedang, dan kebutuhan aktualisasi diri dalam kategori tinggi, (4) keanggotaan dalam kategori sedang, dan tugas dalam kategori tinggi; (5) terdapat pengaruh motivasi terhadap loyalitas; secara simultan terdapat pengaruh faktor-faktor motivasi terhadap faktor keanggotaan, secara parsial faktor motivasi yang berpengaruh terhadap faktor keanggotaan adalah kebutuhan penghargaan dan kebutuhan aktualisasi diri, secara simultan terdapat pengaruh faktorfaktor motivasi terhadap faktor tugas, secara parsial faktor motivasi yang berpengaruh terhadap faktor tugas adalah kebutuhan sosial, kebutuhan penghargaan, dan kebutuhan aktualisasi diri.
\end{abstract}

Kata kunci: motivasi; loyalitas Anggota OSIS

\section{Pendahuluan}

Organisasi Siswa Intra Sekolah (OSIS) merupakan organisasi yang wajib dibentuk di setiap sekolah. Menurut Champoux (dalam Burhanuddin, 2016), organisasi adalah suatu sistem yang mempunyai struktur dan perencanaan, di dalamnya anggota bekerja dan berhubungan satu sama lain dengan suatu koordinasi, kooperatif, dan dorongan-dorongan guna mencapai tujuan-tujuan organisasi. Organisasi Siswa Intra Sekolah (OSIS) adalah sebuah tempat untuk mengembangkan bakat, minat dan potensi peserta didik. Sesuai dengan UndangUndang Nomor 20 Tahun 2003 tentang Sistem Pendidikan Nasional Pasal 12 Ayat 1b yang menyebutkan, bahwa "setiap peserta didik pada satuan pendidikan berhak mendapatkan 
pelayanan pendidikan sesuai dengan bakat, minat, dan kemampuannya". Dapat dipahami bahwa menjadi Anggota OSIS yang aktif mampu meningkatkan bakat dan minat dari peserta didik tersebut.

OSIS merupakan sebuah wadah pelaksanaan dan pengembangan kegiatan ekstrakurikuler. Menurut Gunawan dan Benty (2017), kegiatan ekstrakurikuler merupakan kegiatan yang tidak masuk dalam jadwal pelajaran, namun secara tidak langsung dapat menunjang kegiatan intrakurikuler. Meskipun tidak dirasakan secara langsung namun pengembangan pribadi peserta didik menjadi efek jangka panjangnya. Berdasarkan paparan tersebut, dapat disimpulkan bahwa peran dari OSIS sangatlah penting demi terbentuknya karakter peserta didik.

Peran OSIS tidak akan maksimal tanpa adanya loyalitas dari anggota. Menurut Hurriyati (2005), loyalitas merupakan komitmen anggota untuk bertahan berada di organisasi dan mengikuti kegiatan berulang secara konsisten di masa depan, meskipun ada sebuah pengaruh yang mengakibatkan perubahan perilaku. Loyalitas anggota berkaitan dengan partisipasi yang ditunjukkan oleh anggota. Pada kenyataanya tingkat loyalitas Anggota OSIS masih belum maksimal. Mereka tidak mengikuti semua kegiatan yang diselenggarakan OSIS dengan antusias. Kebanyakan dari mereka mengikuti kegiatan OSIS disebabkan beberapa alasan saja.

Loyalitas yang ditunjukkan Anggota OSIS juga dipengaruhi oleh motivasi. Sejalan penelitian Mehta (2010), salah satu faktor mendasar loyalitas adalah motivasi. Menurut Moorhead \& Griffin (2013), motivasi adalah serangkaian dorongan yang berasal dari dalam diri individu dan mengakibatkan berperilaku tertentu. Hal ini menyebabkan seseorang mempunyai inisiatif sehingga peserta didik termotivasi melaksanakan kepentingan organisasi.

Perbedaan penelitian ini dengan penelitian lain terletak pada ruang lingkup penelitian yaitu Anggota OSIS. Penelitian ini penting dilakukan karena penelitian ini tidak hanya mencari faktor-faktor motivasi saja tetapi juga akan dipaparkan pengaruh dari masing-masing faktor motivasi terhadap loyalitas Anggota OSIS.

\section{Metode}

Penelitian ini tergolong penelitian kuantitatif dengan desain correlational multivariate. Teknik analisis yang akan digunakan adalah: (1) analisis faktor; (2) deskriptif; (3) regresi; dan (4) regresi ganda. Populasi yang digunakan adalah peserta didik kelas XI SMA Negeri se-Kota Malang dengan jumlah populasi sebesar 3065 peserta didik. Pengambilan sampel menggunakan teknik simple random sampling dan purposive sampling. Untuk mengetahui ukuran sampel dari populasi menggunakan rumus Slovin (Darmawan, 2014) dan besar sampel yang diperoleh adalah 353 peserta didik.

Teknik pengumpulan data yang digunakan adalah penyebaran kuesioner. Jenis kuesioner yang digunakan yaitu kuesioner tertutup. Kuesioner akan diuji coba kepada 50 peserta didik sebagai responden. Angket yang disebarkan untuk uji coba berjumlah sebanyak 58 item pernyataan, dengan jumlah variabel motivasi sebanyak 40 dan loyalitas sebanyak 18 item pernyataan. Uji validitas menggunakan analisis faktor dengan pendekatan Principal Component Analysis dengan menggunakan Dimension Reduction pada SPSS 21.0 for Windows dimana nilai Communalities harus $\geq 0,3$. Masing-masing item pernyataan pada instrumen uji coba diuji secara rinci untuk mengelompokkan jenis item yang sesuai dengan indikator dari variabel. Hasil dari analisis faktor menunjukkan bahwa terdapat 53 item valid dengan nilai 
Communalities $\geq 0,3$ dan 5 item yang tidak valid yakni nomor 1, 5, 33, 49 dan 50 dengan hasil Communalities $\leq 0,3$ (Ghozali, 2016).

Setelah diketahui validitas masing-masing item kuesioner, selanjutnya akan dihitung reliabilitas masing-masing variabel. Reliabilitas disetiap faktor diuji dengan melihat Reliability Analysis. Tabel 1 akan menyajikan tentang hasil perhitungan reliabilitas sebagai berikut.

Tabel 1. Reliabilitas Variabel Penelitian

\begin{tabular}{lc}
\hline \multicolumn{1}{c}{ Variabel } & Reliabilitas Statistic (Cronbach's Alpha) \\
\hline Motivasi & 0,951 \\
Faktor Kebutuhan Fisologis & 0,649 \\
Faktor Kebutuhan Keamanan & 0,867 \\
Faktor Kebutuhan Sosial & 0,890 \\
Faktor Kebutuhan Penghargaan & 0,826 \\
Faktor Kebutuhan Aktualisasi Diri & 0,860 \\
Loyalitas & 0,919 \\
Faktor Keanggotaan & 0,820 \\
Faktor Tugas & 0,895 \\
\hline
\end{tabular}

\section{Hasil dan Pembahasan}

\subsection{Hasil}

Berikut adalah hasil perhitungan Principle Component Analysis variabel motivasi akan dijabarkan pada Tabel 2.

Tabel 2. Hasil Perhitungan Principle Component Analysis Variabel Motivasi

\begin{tabular}{|c|c|c|c|c|c|c|c|}
\hline Factor & $\begin{array}{c}\text { KMO > } \\
0,5\end{array}$ & $\begin{array}{c}\text { Barlett's } \\
\text { Test of } \\
\text { Sphericity }\end{array}$ & $\begin{array}{c}\text { Batas } \\
\text { kriteria } \\
\text { maks Sig }\end{array}$ & $\begin{array}{l}\text { Hasil } \\
\text { Nilai } \\
\text { Sig < } \\
0,05\end{array}$ & $\begin{array}{l}\text { Nomor } \\
\text { Item }\end{array}$ & $\begin{array}{l}\text { Communaliti } \\
\text { es Uji Coba }\end{array}$ & $\begin{array}{c}\text { Communalities } \\
\text { Studi Utama }\end{array}$ \\
\hline $\begin{array}{l}\text { Kebutuhan } \\
\text { Fisiologis }\end{array}$ & 0,798 & 744,043 & 0,05 & 0,00 & $\begin{array}{l}1 \\
2 \\
3 \\
4 \\
5 \\
6\end{array}$ & $\begin{array}{l}0,409 \\
0,353 \\
0,343 \\
0,344 \\
0,414 \\
0,304\end{array}$ & $\begin{array}{l}0,464 \\
0,641 \\
0,616 \\
0,564 \\
0,429 \\
0,491\end{array}$ \\
\hline $\begin{array}{l}\text { Kebutuhan } \\
\text { Keamanan }\end{array}$ & 0,828 & 663,621 & 0,05 & 0,00 & $\begin{array}{c}8 \\
9 \\
10 \\
11 \\
12 \\
13\end{array}$ & $\begin{array}{l}0,658 \\
0,383 \\
0,663 \\
0,563 \\
0,660 \\
0,557\end{array}$ & $\begin{array}{l}0,405 \\
0,482 \\
0,591 \\
0,592 \\
0,593 \\
0,499\end{array}$ \\
\hline $\begin{array}{l}\text { Kebutuhan } \\
\text { Sosial }\end{array}$ & 0,845 & 1352,406 & 0,05 & 0,00 & $\begin{array}{l}14 \\
15 \\
16 \\
17 \\
18 \\
19 \\
20\end{array}$ & $\begin{array}{l}0,524 \\
0,588 \\
0,485 \\
0,475 \\
0,686 \\
0,656 \\
0,619\end{array}$ & $\begin{array}{l}0,442 \\
0,542 \\
0,409 \\
0,632 \\
0,551 \\
0,496 \\
0,307\end{array}$ \\
\hline
\end{tabular}




\begin{tabular}{|c|c|c|c|c|c|c|c|}
\hline Factor & $\begin{array}{c}\text { KMO > } \\
0,5\end{array}$ & $\begin{array}{c}\text { Barlett's } \\
\text { Test of } \\
\text { Sphericity }\end{array}$ & $\begin{array}{c}\text { Batas } \\
\text { kriteria } \\
\text { maks Sig }\end{array}$ & $\begin{array}{l}\text { Hasil } \\
\text { Nilai } \\
\text { Sig < } \\
0,05\end{array}$ & $\begin{array}{l}\text { Nomor } \\
\text { Item }\end{array}$ & $\begin{array}{l}\text { Communaliti } \\
\text { es Uji Coba }\end{array}$ & $\begin{array}{l}\text { Communalities } \\
\text { Studi Utama }\end{array}$ \\
\hline \multirow{11}{*}{$\begin{array}{l}\text { Kebutuhan } \\
\text { Penghargaan }\end{array}$} & \multirow{11}{*}{0,820} & \multirow{11}{*}{920,153} & \multirow{11}{*}{0,05} & \multirow{11}{*}{0,00} & 21 & 0,372 & 0,526 \\
\hline & & & & & 22 & 0,594 & 0,477 \\
\hline & & & & & 23 & & 0,356 \\
\hline & & & & & 24 & $\begin{array}{l}0,300 \\
036 ?\end{array}$ & 0,418 \\
\hline & & & & & 25 & $\begin{array}{l}0,362 \\
0339\end{array}$ & 0,352 \\
\hline & & & & & 26 & $0,3 \angle 9$ & 0,445 \\
\hline & & & & & 27 & 0,311 & 0,527 \\
\hline & & & & & 28 & $\begin{array}{r}0,623 \\
0478\end{array}$ & 0,543 \\
\hline & & & & & 29 & $0,4 / 8$ & 0,445 \\
\hline & & & & & 30 & 0,300 & 0,351 \\
\hline & & & & & 31 & $\begin{array}{l}0,530 \\
0,602\end{array}$ & 0,316 \\
\hline \multirow{6}{*}{$\begin{array}{l}\text { Kebutuhan } \\
\text { Aktualisasi } \\
\text { diri }\end{array}$} & \multirow{6}{*}{0,783} & \multirow{6}{*}{714,477} & \multirow{6}{*}{0,05} & \multirow{6}{*}{0,00} & 32 & 0,669 & 0,627 \\
\hline & & & & & 33 & 0,642 & 0,657 \\
\hline & & & & & 34 & 0,562 & 0,516 \\
\hline & & & & & 35 & 0,607 & 0,451 \\
\hline & & & & & 36 & 0,478 & 0,427 \\
\hline & & & & & 37 & 0,578 & 0,405 \\
\hline
\end{tabular}

Berdasarkan Tabel 2 hasil analisis faktor yang digunakan pada variabel motivasi dapat dipertanggungjawabkan.

Hasil perhitungan reliabilitas variabel motivasi akan dijabarkan pada Tabel 3.

Tabel 3. Hasil Perhitungan Reliabilitas Variabel Motivasi

\begin{tabular}{lcc}
\hline \multicolumn{1}{c}{ Skala (Scale) Pengukuran } & \multicolumn{2}{c}{ Alpha Cronbach } \\
& Hasil Uji Coba & Hasil Studi Utama \\
\hline Faktor Kebutuhan Fisiologis & 0,649 & 0,824 \\
Faktor Kebutuhan Keamanan & 0,867 & 0,819 \\
Faktor Kebutuhan Sosial & 0,890 & 0,866 \\
Faktor Kebutuhan Penghargaan & 0,826 & 0,823 \\
Faktor Kebutuhan Aktualisasi Diri & 0,860 & 0,808 \\
\hline
\end{tabular}

Berdasarkan hasil uji coba maupun hasil studi utama diperoleh koefisien menurut Guildford (1956) dapat disimpulkan bahwa faktor-faktor motivasi tersebut reliabel.

Berikut adalah hasil perhitungan Principle Component Analysis variabel loyalitas akan dijabarkan pada Tabel 4. 
Tabel 4. Hasil Perhitungan Principle Component Analysis Variabel Motivasi

\begin{tabular}{|c|c|c|c|c|c|c|c|}
\hline Factor & $\begin{array}{l}\text { KMO > } \\
0,5\end{array}$ & $\begin{array}{l}\text { Barlett's } \\
\text { Test of } \\
\text { Sphericity }\end{array}$ & $\begin{array}{l}\text { Batas } \\
\text { kriteria } \\
\text { maks Sig }\end{array}$ & $\begin{array}{l}\text { Hasil } \\
\text { Nilai } \\
\text { Sig < } \\
0,05\end{array}$ & $\begin{array}{l}\text { Nomor } \\
\text { Item }\end{array}$ & $\begin{array}{l}\text { Communalities } \\
\text { Uji Coba }\end{array}$ & $\begin{array}{l}\text { Communalities } \\
\text { Studi Utama }\end{array}$ \\
\hline \multirow{5}{*}{ Keanggotaan } & 0,745 & 259,336 & 0,05 & 0,00 & 1 & 0,309 & 0,331 \\
\hline & & & & & 4 & 0,426 & 0,513 \\
\hline & & & & & 5 & 0,674 & 0,396 \\
\hline & & & & & 6 & 0,492 & 0,529 \\
\hline & & & & & 7 & 0,518 & 0,466 \\
\hline \multirow{9}{*}{ Tugas } & 0,878 & 1211,774 & 0,05 & 0,00 & 8 & 0,597 & 0,534 \\
\hline & & & & & 9 & 0,733 & 0,548 \\
\hline & & & & & 10 & 0,616 & 0,527 \\
\hline & & & & & 11 & 0,330 & 0,472 \\
\hline & & & & & 12 & 0,387 & 0,484 \\
\hline & & & & & 13 & 0,546 & 0,425 \\
\hline & & & & & 14 & 0,527 & 0,488 \\
\hline & & & & & 15 & 0,585 & 0,511 \\
\hline & & & & & 16 & 0,630 & 0,376 \\
\hline
\end{tabular}

Berdasarkan Tabel 4 hasil analisis faktor yang digunakan pada variabel loyalitas dapat dipertanggungjawabkan.

Hasil perhitungan realibilitas variabel loyalitas akan dijabarkan pada Tabel 5.

Tabel 5 Hasil Perhitungan Reliabilitas Variabel Loyalitas

\subsubsection{Faktor Kebutuhan Fisiologis}

Faktor kebutuhan fisiologis diukur dengan menggunakan 4 indikator yang terdiri dari: (1) Kecukupan pendukung makan/minum; (2) sarana dan prasarana memadai; (3) eksistensi gender, dan (4) imbalan yang didapatkan. Panjang kelas interval pada faktor kebutuhan fisiologis adalah 6. Hasil tersebut juga untuk mengetahui frekuensi dan persentase dari masing-masing kategori, seperti pada Tabel 6.

Tabel 6. Distribusi Frekuensi Faktor Kebutuhan Fisiologis

\begin{tabular}{|c|c|c|c|}
\hline Interval & Kualifikasi & Frekuensi & Presentase \\
\hline $7-12$ & Rendah & 15 & 4,2 \\
\hline $13-18$ & Sedang & 154 & 43,6 \\
\hline$\geq 19$ & Tinggi & 184 & 52,1 \\
\hline \multicolumn{2}{|c|}{ Total } & 353 & 100 \\
\hline
\end{tabular}

Berdasarkan Tabel 6 dapat disimpulkan, bahwa persentase faktor kebutuhan fisiologis pada Anggota OSIS dalam kategori 'tinggi', yakni sebesar 52,1\% atau sebanyak 184 anggota.

\subsubsection{Faktor Kebutuhan Keamanan}

Faktor kebutuhan keamanan terdiri dari 3 indikator yaitu: (1) keamanan fisik; (2) keamanan psikis; dan (3) keamanan lingkungan. Data faktor kebutuhan keamanan ini diperoleh dari angket yang berjumlah 6 item dengan 4 alternatif jawaban. Panjang kelas 
interval, pada faktor kebutuhan keamanan adalah 5. Hasil tersebut juga untuk mengetahui frekuensi dan persentase dari masing-masing kategori, seperti pada Tabel 7.

Tabel 7. Distribusi Frekuensi Faktor Kebutuhan Keamanan

\begin{tabular}{|c|c|c|c|}
\hline Interval & Kualifikasi & Frekuensi & Presentase \\
\hline 8-12 & Rendah & 7 & 2,0 \\
\hline $13-17$ & Sedang & 117 & 33,1 \\
\hline$\geq 18$ & Tinggi & 229 & 64,9 \\
\hline \multicolumn{2}{|c|}{ Total } & 353 & 100 \\
\hline
\end{tabular}

Berdasarkan Tabel 7 dapat diketahui bahwa persentase faktor kebutuhan keamanan pada Anggota OSIS dalam kategori 'tinggi', yakni sebesar 64,9\% atau sebanyak 229 anggota.

\subsubsection{Faktor Kebutuhan Sosial}

Faktor kebutuhan sosial diukur dengan menggunakan 5 indikator yaitu: (1) kebutuhan akan rasa kasih sayang; (2) menjalin hubungan yang harmonis; (3) mendapat banyak teman; (4) memiliki tanggung jawab; dan (5) mampu mempengaruhi orang lain. Panjang kelas interval, pada faktor kebutuhan sosial adalah 8. Hasil tersebut juga untuk mengetahui frekuensi dan persentase dari masing-masing kategori, seperti pada Tabel 8.

Tabel 8. Distribusi Frekuensi Faktor Kebutuhan Sosial

\begin{tabular}{cccc}
\hline Interval & Kualifikasi & Frekuensi & Presentase \\
\hline $12-19$ & Rendah & 6 & 1,7 \\
$20-27$ & Sedang & 96 & 21,2 \\
$\geq 28$ & Tinggi & 251 & 71,1 \\
\hline \multicolumn{2}{c}{ Total } & 353 & 100 \\
\hline
\end{tabular}

Berdasarkan Tabel 8, persentase faktor kebutuhan sosial pada Anggota OSIS dalam kategori 'tinggi', yakni sebesar 71,1\% atau sebanyak 251 anggota.

\subsubsection{Faktor Kebutuhan Penghargaan}

Faktor kebutuhan penghargaan terdiri atas 3 indikator yaitu: (1) kebutuhan akan dihormati; (2) pengakuan dari organisasi; dan (3) dukungan kebijakan organisasi. Panjang kelas interval pada faktor kebutuhan penghargaan adalah 7. Hasil tersebut juga untuk mengetahui frekuensi dan persentase dari masing-masing kategori, seperti pada Tabel 9.

Tabel 9. Distribusi Frekuensi Faktor Kebutuhan Penghargaan

\begin{tabular}{cccc}
\hline Interval & Kualifikasi & Frekuensi & Presentase \\
\hline $14-20$ & Rendah & 21 & 5,9 \\
$21-27$ & Sedang & 194 & 55,0 \\
$\geq 28$ & Tinggi & 138 & 39,1 \\
\hline \multicolumn{2}{c}{ Total } & 353 & 100 \\
\hline
\end{tabular}

Berdasarkan Tabel 9, persentase faktor kebutuhan penghargaan pada Anggota OSIS dalam kategori 'sedang', yakni sebesar 55,0\% atau sebanyak 194 anggota. 


\subsubsection{Faktor Kebutuhan Aktualisasi Diri}

Faktor kebutuhan aktualisasi diri terdiri atas 3 indikator yaitu: (1) kesempatan meningkatkan potensi; (2) kemajuan organisasi; dan (3) keinginan organisasi. Panjang kelas interval pada faktor kebutuhan aktualisasi diri adalah 5 . Hasil tersebut juga untuk mengetahui frekuensi dan persentase dari masing-masing kategori, seperti pada Tabel 10.

Tabel 10. Distribusi Frekuensi Faktor Kebutuhan Aktualisasi Diri

\begin{tabular}{|c|c|c|c|}
\hline Interval & Kualifikasi & Frekuensi & Presentase \\
\hline $14-20$ & Rendah & 21 & 5,9 \\
\hline $21-27$ & Sedang & 194 & 55,0 \\
\hline$\geq 28$ & Tinggi & 138 & 39,1 \\
\hline \multicolumn{2}{|c|}{ Total } & 353 & 100 \\
\hline
\end{tabular}

Berdasarkan Tabel 10, persentase faktor kebutuhan aktualisasi diri pada Anggota OSIS dalam kategori 'tinggi', yakni sebesar 75,1\% atau sebanyak 265 anggota.

Deskripsi tingkat loyalitas Anggota OSIS SMA Negeri se-Kota Malang akan dijabarkan masing-masing faktor loyalitas yang dihasilkan, adalah sebagai berikut:

\subsubsection{Keanggotaan}

Faktor keanggotaan diukur dengan menggunakan 4 indikator yang terdiri dari: (1) konformitas keanggotaan; (2) diterima dalam organisasi; (3) ketaatan terhadap organisasi; dan (4) kejujuran dalam organisasi. Panjang kelas interval pada faktor keanggotaan adalah 4. Hasil tersebut juga untuk mengetahui frekuensi dan persentase dari masing-masing kategori, seperti pada Tabel 11.

Tabel 11. Distribusi Frekuensi Faktor Keanggotaan

\begin{tabular}{cccc}
\hline Interval & Kualifikasi & Frekuensi & Presentase \\
\hline $8-11$ & Rendah & 11 & 3,1 \\
$12-15$ & Sedang & 210 & 59,5 \\
$\geq 16$ & Tinggi & 132 & 37,4 \\
\hline \multicolumn{2}{c}{ Total } & 353 & 100 \\
\hline
\end{tabular}

Berdasarkan Tabel 11, bahwa persentase faktor keanggotaan pada Anggota OSIS dalam kategori 'sedang', yakni sebesar 59,5\% atau sebanyak 210 anggota.

\subsubsection{Tugas}

Faktor tugas diukur dengan menggunakan 4 indikator yang terdiri dari: (1) pemanfaatan waktu; (2) penyelesaian tugas; (3) melaksanakan hasil keputusan organisasi; dan (4) pengabdian pada organisasi. Panjang kelas interval pada faktor tugas adalah 8. Hasil tersebut juga untuk mengetahui frekuensi dan persentase dari masing-masing kategori, seperti pada Tabel 12. 
Tabel 12. Distribusi Frekuensi Faktor Tugas

\begin{tabular}{cccc}
\hline Interval & Kualifikasi & Frekuensi & Presentase \\
\hline $12-19$ & Rendah & 21 & 5,9 \\
$20-23$ & Sedang & 58 & 16,4 \\
$\geq 24$ & Tinggi & 274 & 77,6 \\
\hline \multicolumn{2}{c}{ Total } & 353 & 100 \\
\hline
\end{tabular}

Berdasarkan Tabel 12, persentase faktor tugas pada Anggota OSIS dalam kategori 'tinggi', yakni sebesar $77,6 \%$ atau sebanyak 274 anggota.

\subsubsection{Pengaruh Faktor-Faktor Motivasi Terhadap Faktor Loyalitas Anggota OSIS di SMA Negeri Se-Kota Malang}

Deskripsi hasil penelitian ini diuji setelah dilakukan analisis faktor dengan pendekatan Principle Component Analysis. Berikut ini adalah ringkasan hasil penelitian dapat dilihat pada Tabel 13.

Tabel 13. Ringkasan Analisis Deskriptif Faktor-Faktor Variabel Koefisien Penelitian

\begin{tabular}{|c|c|c|c|c|c|c|c|c|c|}
\hline $\begin{array}{c}\text { Variabel } \\
\text { Koefisien }\end{array}$ & Motivasi & Fisiologis & Keamanan & Sosial & $\begin{array}{c}\text { Pengharga } \\
\text { an }\end{array}$ & $\begin{array}{c}\text { Akualisasi } \\
\text { Diri }\end{array}$ & Loyalitas & $\begin{array}{c}\text { Keanggota } \\
\text { an }\end{array}$ & Tugas \\
\hline Rata-rata & 5,72024 & 5,23508 & 5,13688 & 5,82705 & 5,17865 & 5,70565 & 5,13634 & 5,79226 & 5,25015 \\
\hline Skewness & 0,107 & $-0,407$ & $-0,152$ & $-0,189$ & 0,098 & $-0,153$ & 0,235 & 0,069 & 0,103 \\
\hline jusi & Normal & Normal & Normal & Normal & Normal & Normal & Normal & Normal & Normal \\
\hline Kurtosis & 0,176 & 0,210 & $-0,035$ & 0,663 & $-0,053$ & 0,448 & 0,170 & 0,636 & 0,270 \\
\hline (Distribusi & Normal & Normal & Normal & Normal & Normal & Normal & Normal & Normal & Normal \\
\hline $\begin{array}{l}\text { Skor } \\
\text { Minimum }\end{array}$ & $-3,56681$ & $-3,63646$ & $-3,41018$ & $-4,06068$ & $-3,01156$ & $-3,95851$ & $-2,85505$ & $-3,54094$ & $-3,15975$ \\
\hline $\begin{array}{l}\text { Skor } \\
\text { Maksimum }\end{array}$ & 2,15342 & 1,59862 & 1,72669 & 1,76636 & 2,16708 & 1,74714 & 2,28129 & 2,25131 & 2,09039 \\
\hline $\mathrm{N}$ (Sampel) & 353 & 353 & 353 & 353 & 353 & 353 & 353 & 353 & 353 \\
\hline
\end{tabular}

\subsubsection{Pengaruh Motivasi Terhadap Loyalitas}

Analisis data menggunakan teknik regresi menunjukkan nilai signifikansi 0,000 $<0,05$ pada taraf kepercayaan $\alpha 0,05$. Sehingga $\mathrm{H}_{0}$ ditolak (rejected). Berdasarkan ketentuan tersebut, maka motivasi mempunyai pengaruh terhadap loyalitas Anggota OSIS di SMA Negeri se-Kota Malang. Koefisien determinan $\left(R_{\text {square }}\right)=0,572$ menjelaskan bahwa sumbangan efektif sebesar $57,2 \%$ dan $42,8 \%$ terdapat sumbangan lain dari luar motivasi.

\subsubsection{Pengaruh Faktor Kebutuhan Fisiologis, Keamanan, Sosial, Penghargaan dan Aktualisasi Diri Terhadap Faktor Loyalitas Keanggotaan}

Secara simultan faktor kebutuhan fisiologis, keamanan, sosial, penghargaan dan aktualisasi diri berpengaruh terhadap faktor loyalitas keanggotaan Anggota OSIS di SMA Negeri se-Kota Malang. Koefisien determinan $\left(R_{\text {square }}\right)=0,488$ menjelaskan bahwa sumbangan efektif sebesar $48,8 \%$ dan $51,2 \%$ terdapat sumbangan lain dari luar faktor-faktor motivasi 
yang turut memberikan kontribusi pada loyalitas Anggota OSIS SMA Negeri se-Kota Malang. Faktor-faktor motivasi yang berpengaruh terhadap faktor loyalitas keanggotaan adalah faktor kebutuhan penghargaan dan aktualisasi diri. Tabel 14 akan menjabarkan ringkasan hasil analisis regresi struktur I.

Tabel 14. Ringkasan Hasil Analisis Regresi Ganda Struktur I

\begin{tabular}{|c|c|c|c|c|c|}
\hline \multirow[t]{2}{*}{ Model } & \multicolumn{2}{|c|}{$\begin{array}{l}\text { Unstandardized } \\
\text { Coefficients }\end{array}$} & \multirow{2}{*}{$\begin{array}{c}\text { Standardized } \\
\text { Coefficients } \\
\text { B }\end{array}$} & \multirow[t]{2}{*}{$\mathbf{t}$} & \multirow[t]{2}{*}{ Sig. } \\
\hline & B & Std Error & & & \\
\hline (Constant) & $2,176 \mathrm{E}-17$ & 0,038 & & 0,000 & 1,000 \\
\hline Fisiologis & $-0,010$ & 0,055 & 0,010 & $-0,189$ & 0,850 \\
\hline Keamanan & 0,110 & 0,057 & 0,110 & 1,945 & 0,053 \\
\hline Sosial & 0,124 & 0,066 & 0,124 & 1,882 & 0,061 \\
\hline Penghargaan & 0,265 & 0,066 & 0,265 & 3,997 & 0,000 \\
\hline Aktualisasi Diri & 0,319 & 0,054 & 0,319 & 5,880 & 0,000 \\
\hline
\end{tabular}

\subsubsection{Pengaruh Faktor Kebutuhan Fisiologis, Keamanan, Sosial, Penghargaan dan Aktualisasi Diri Terhadap Faktor Loyalitas Tugas}

Secara simultan faktor motivasi kebutuhan fisiologis, keamanan, sosial, penghargaan aktualsasi diri mempunyai pengaruh terhadap faktor loyalitas tugas loyalitas. Koefisien determinan $\left(R_{\text {square }}\right)=0,540$ menjelaskan bahwa sumbangan efektif sebesar $54 \%$ dan $46 \%$ terdapat sumbangan lain dari luar faktor motivasi kebutuhan fisiologis, keamanan, sosial, penghargaan aktualsasi diri yang turut memberikan kontribusi pada loyalitas Anggota OSIS SMA Negeri se-Kota Malang. Faktor-faktor motivasi yang berpengaruh terhadap faktor loyalitas tugas adalah faktor kebutuhan sosial, penghargaan dan aktualisasi diri. Tabel 15 akan menjabarkan ringkasan hasil analisis regresi struktur II.

Tabel 15. Ringkasan Hasil Analisis Regresi Ganda Struktur II

\begin{tabular}{|c|c|c|c|c|c|}
\hline \multirow[t]{2}{*}{ Model } & \multicolumn{2}{|c|}{ Unstandardized Coefficients } & \multirow{2}{*}{$\begin{array}{c}\text { Standardized } \\
\text { Coefficients } \\
\text { B }\end{array}$} & \multirow[t]{2}{*}{$\mathbf{t}$} & \multirow[t]{2}{*}{ Sig. } \\
\hline & B & Std Error & & & \\
\hline (Constant) & $-9,444 \mathrm{E}-17$ & 0,038 & & 0,000 & 1,000 \\
\hline Fisiologis & 0,065 & 0,055 & 0,010 & $-0,189$ & 0,850 \\
\hline Keamanan & 0,091 & 0,057 & 0,110 & 1,945 & 0,053 \\
\hline Sosial & 0,226 & 0,066 & 0,124 & 1,882 & 0,061 \\
\hline Penghargaan & 0,315 & 0,066 & 0,265 & 3,997 & 0,000 \\
\hline $\begin{array}{l}\text { Aktualisasi } \\
\text { Diri }\end{array}$ & 0,160 & 0,054 & 0,319 & 5,880 & 0,000 \\
\hline
\end{tabular}

\subsection{Pembahasan}

\subsubsection{Faktor-Faktor Motivasi Anggota OSIS di SMA Negeri se-Kota Malang}

\subsubsection{Faktor Kebutuhan Fisologis}

Menurut Siagian (2004), kebutuhan fisiologis merupakan paling mendasar. Menurut Amir (2017), kebutuhan fisiologis merupakan kebutuhan yang harus terpuaskan terlebih 
dahulu sebelum beranjak ke kebutuhan berikutnya. Hal ini berarti seorang individu akan melakukan apa saja demi terpenuhinya kebutuhan ini. Seorang individu akan tidak akan memenuhi kebutuhan lain sebelum kebutuhan fisiologis terpenuhi. Implikasinya dalam organisasi, peserta didik selaku Anggota OSIS akan patuh dan taat terhadap perintah OSIS apabila dapat memenuhi kebutuhan fisiologisnya.

\subsubsection{Faktor Kebutuhan Keamanan}

Menurut Siagian (2004), kebutuhan keamanan dilihat dari berbagai aspek tidak hanya dalam arti keamanan fisik, tetapi juga harus melihat psikologis dan lingkungan. Mengingat pentingnya suatu keamanan dalam sebuah organisasi, kebutuhan keamanan ini sangat penting untuk diperhatikan. Hal ini sesuai dengan Robbin dan Judge (2007) yang menyatakan bahwa kebutuhan keamanan meliputi rasa aman dilindungi dari bahaya fisik dan emosional. Sedangkan menurut Mustiningsih (2013), kebutuhan keamanan merupakan kebutuhan untuk stabilitas dan perlindungan dari ancaman. Implikasinya dalam dunia organisasi, anggota selalu membutuhkan rasa aman dalam organisasi yang menaunginya, dengan adanya rasa aman, anggota akan lebih nyaman berada dalam organisasi tersebut.

\subsubsection{Faktor Kebutuhan Sosial}

Menurut Amir (2017) kebutuhan sosial adalah kebutuhan untuk bersosialisasi. Sementara menurut Siagian (2004), manusia merupakan makhluk sosial. Sebagai Anggota OSIS, peserta didik mempunyai berbagai kebutuhan yang berkisar pada pengakuan atas keberadaannya sebagai anggota dari organisasi tersebut. Alasan peserta didik aktif dalam kegiatan OSIS salah satunya adalah untuk memenuhi kebutuhan sosialnya, dimana mereka membutuhkan rasa kasih sayang, menjalin hubungan yang harmonis, mendapatkan banyak teman, memiliki tanggung jawab serta dapat memeberi pengaruh untuk orang lain. Robbin dan Judge (2007), menyebutkan bahwa kebutuhan sosial terdiri atas rasa kasih sayang, kepemilikan, penerimaan dan persahabatan. Pada dasarnya peserta didik membutuhkannya untuk mengembangkan potensi bakat dan minat.

\subsubsection{Faktor Kebutuhan Penghargaan}

Menurut Mustiningsih (2013), kebutuhan penghargaan adalah kebutuhan akan penghargaan pengakuan, status, dan sebagainya. Sejalan dengan pendapat Robbin dan Judge (2007), yang menyebutkan bahwa kebutuhan penghargaan meliputi faktor internal dan eksternal. Faktor internal yaitu seperti: hormat diri, otonomi, dan pencapaian. Sementara faktor eksternal yaitu seperti: status, pengakuan, dan perhatian. Menurut Siagian (2004), harga diri merupakan salah satu ciri manusia. Karena keberadaan dan status seseorang biasanya dipandang sebagai pemenuhan hak seseorang, terutama anggota organisasi.

\subsubsection{Faktor Kebutuhan Aktualisasi Diri}

Kebutuhan aktualisasi diri menurut Robbin dan Judge (2007) adalah suatu keinginan untuk menjadi sesuai kemampuannya seperti: pertumbuhan, pencapaian potensi seseorang, dan pemenuhan diri sendiri. Hal ini dapat dipahami bahwa kebutuhan ini adalah suatu kebutuhan untuk mengeluarkan segala potensi yang ada di dalam diri seseorang. Sesuai dengan pendapat Amir (2017), semua orang pada akhirnya harus mengeluarkan segala potensi 
yang ada dalam dirinya, seperti: ingin berkembang, sesuai dengan cita-cita diri terdalamnya. Hal tersebut tentunya dapat memberikan pengaruh yang lebih besar bagi organisasi.

\subsubsection{Faktor-Faktor Loyalitas Anggota OSIS di SMA Negeri Se-Kota Malang}

Ada dua jenis faktor loyalitas yaitu: faktor keanggotaan dan faktor tugas. Berikut ini adalah pembahasan dari kedua faktor loyalitas yang menjadi fokus dalam penelitian ini.

\subsubsection{Faktor Keanggotaan}

Menurut Darwis (2017), keanggotaan dalam organsasi sangat menentukan berjalan tidaknya suatu organisasi. Peran dari anggota organisasi menentukan dinamika organisasi dapat berjalan sesuai harapan atau tidak. Hal ini sesuai dengan pendapat Kleinig (2017) yang menyebutkan bahwa loyalitas didorong sebagai aspek afiliasi atau keanggotaan dalam oganisasi. Dapat disimpulkan bahwa organisasi sangat membutuhkan peran dari anggota organisasi. Karena peran anggota sangat menentukan tercapainya tujuan dari organisasi tersebut.

\subsubsection{Faktor Tugas}

Loyalitas pada tugas merupakan suatu dorongan internal seseorang untuk tekun dalam melaksanakan tugasnya, berarti individu tersebut telah mengikat diri untuk bertanggungjawab pada tugasnya. Sesuai dengan pendapat Sutisna (2012), loyalitas pada tugas merupakan suatu dorongan dari dalam diri yang mendorong seseorang untuk rajin dalam menyelesaikan tugasnya walaupun banyak halangan dalam melaksanakan tugas yang telah menjadi tanggungjawabnya. Loyalitas pada tugas perlu dimiliki oleh setiap anggota organisasi untuk menunjang keberhasilan pencapaian tujuan organisasi. Semakin loyal pada tugas semakin baik pula kineja dalam organisasi.

\subsubsection{Pengaruh Faktor Motivasi Terhadap Faktor Loyalitas Anggota OSIS di SMA Negeri Se-Kota Malang}

\subsubsection{Pengaruh Motivasi Terhadap Loyalitas}

Hasil penelitian menunjukkan pengujian hipotesis utama, ada pengaruh motivasi terhadap loyalitas Anggota OSIS di SMA Negeri se-Kota Malang. Penelitian Simbolon (2015), ada pengaruh signifikan motivasi terhadap loyalitas. Hasil penelitian tersebut menunjukkan ada pengaruh motivasi terhadap loyalitas. Menurut Mehta (2010), salah satu faktor yang mendasari loyalitas adalah motivasi. Peserta didik akan loyal apabila mereka mempunyai motivasi, dan sebaliknya peserta didik akan tidak loyal apabila mereka tidak mempunyai motivasi.

\subsubsection{Pengaruh Faktor Motivasi Kebutuhan Fisiologis, Keamanan, Sosial, Penghargaan, dan Aktualisasi Diri Terhadap Faktor Loyalitas Keanggotaan}

Hasil penelitian ini menunjukkan bahwa motivasi yang ada akan menghasilkan sikap loyal Anggota OSIS di SMA Negeri se-Kota Malang. Hal ini sesuai dengan hasil penelitian Sisdawati (2016) menyatakan bahwa ada pengaruh signifikan secara simultan motivasi 
terhadap loyalitas. Faktor-faktor motivasi yang berpengaruh terhadap faktor loyalitas Anggota OSIS di SMA Negeri se-Kota Malang adalah faktor kebutuhan penghargaan dan aktualisasi diri. Sedangkan ketiga faktor lainnya yaitu faktor kebutuhan fisiologis, kebutuhan keamanan, dan kebutuhan sosial tidak mempunyai pengaruh terhadap faktor loyalitas keanggotaan.

\subsubsection{Pengaruh Faktor Motivasi Kebutuhan Fisiologis, Keamanan, Sosial, Penghargaan, dan Aktualisasi Diri Terhadap Faktor Loyalitas Tugas}

Hasil penelitian secara simultan ada pengaruh faktor motivasi kebutuhan fisiologis, keamanan, sosial, penghargaan dan aktualisasi diri berpengaruh terhadap faktor loyalitas tugas Anggota OSIS di SMA Negeri se-Kota Malang. Hal ini sesuai dengan penelitian Kusuma (2003), memberikan pengaruh signifikan secara simultan motivasi terhadap loyalitas. Faktorfaktor motivasi yang berpengaruh terhadap faktor loyalitas tugas Anggota OSIS di SMA Negeri se-Kota Malang adalah faktor kebutuhan sosial, kebutuhan penghargaan dan aktualisasi diri. Sedangkan kedua faktor lainnya yaitu faktor kebutuhan fisiologis dan kebutuhan keamanan tidak mempunyai pengaruh terhadap faktor loyalitas tugas.

\section{Simpulan}

Kesimpulannya yaitu sebagai berikut: (1) penelitian ini menghasilkan faktor-faktor yang memotivasi Anggota OSIS di SMA Negeri se-Kota Malang, yaitu (a) faktor kebutuhan fisiologis, (b) faktor kebutuhan keamanan, (c) faktor kebutuhan sosial, (d) faktor kebutuhan penghargaan, dan (e) faktor kebutuhan aktualisasi diri; (2) penelitian ini menghasilkan faktorfaktor yang mendorong loyalitas Anggota OSIS di SMA Negeri se-Kota Malang, yaitu (a) faktor keanggotaan dan (b) faktor tugas; (3) tingkat motivasi Anggota OSIS di SMA Negeri se-Kota Malang yaitu (a) faktor kebutuhan fisiologis dalam kategori tinggi, (b) faktor kebutuhan keamanan dalam kategori tinggi, (c) faktor kebutuhan sosial dalam kategori tinggi, (d) faktor kebutuhan penghargaan dalam kategori sedang, dan (e) faktor kebutuhan aktualisasi diri dalam kategori tinggi; (4) tingkat loyalitas Anggota OSIS di SMA Negeri se-Kota Malang yaitu: (a) faktor keanggotaan dalam kategori sedang dan (b) faktor tugas dalam kategori tinggi; dan (5) pengaruh faktor motivasi terhadap faktor loyalitas Anggota OSIS di SMA Negeri se-Kota Malang: (a) terdapat pengaruh motivasi terhadap loyalitas, (b) secara simultan terdapat pengaruh faktor motivasi kebutuhan fisiologis, keamanan, sosial, penghargaan dan aktualisasi diri berpengaruh terhadap faktor loyalitas keanggotaan, (c) secara parsial faktor-faktor motivasi yang berpengaruh terhadap faktor loyalitas adalah faktor kebutuhan penghargaan dan aktualisasi diri, (d) secara simultan terdapat pengaruh faktor motivasi kebutuhan fisiologis, keamanan, sosial, penghargaan dan aktualisasi diri terdapat pengaruh yang signifikan terhadap faktor loyalitas tugas, (i) secara parsial faktor-faktor motivasi yang berpengaruh terhadap faktor loyalitas adalah faktor kebutuhan sosial, penghargaan, dan aktualisasi diri.

\section{Daftar Rujukan}

Amir, M. T. (2017). Perilaku Organisasi. Jakarta: Kencana.

Burhanuddin. (2016). Perilaku Organisasi dalam Manajemen dan Kepemimpinan. Malang: Universitas Negeri Malang.

Darmawan, D. (2014). Metode Penelitian Kuantitatif. Bandung: Remaja Rosdakarya.

Darwis, R. (2017). Pentingnya Peran Anggota dalam Organisasi, (Online), (https://prezi.com/1wpczyxkasz/pentingnya-peran-anggota-dalam-organisasi/) , diakses pada 18 Januari 2018. 
Ghozali, I. (2016). Aplikasi Analisis Multivariete dengan Program IBM SPSS 23. Semarang: Badan Penerbit Universitas Diponegoro.

Guilford, J. P. (1956). Fundamental Statistic in Psychology and Education. New York: Mc Graw-Hill Book Co. Inc. Gunawan, I. \& Benty, D. D. (2017). Manajemen Pendidikan Suatu Pengantar Praktik. Bandung: Penerbit Alfabeta. Hurriyati, R. (2005). Bauran Pemasaran dan Loyalitas Konsumen. Bandung: Alfabeta.

Kleinig, J. (2017). Loyalty. (Online), (https://plato.stanford.edu/entries/loyalty/), diakses pada 4 November 2017.

Kusuma, I. (2003). Pengaruh Motivasi Ekstrinsik Terhadap Loyaljtas Karyawan PT. Industri LJFF Indo Nusantara. (Online), (http://repository.unair.ac.id/50602/), diakses pada 5 Mei 2018.

Mehta, S, dkk. (2010). Employee Loyalty towards Organization -A study of Academicia. Int.J.Buss.Mgt.Eco.Res, 1(1) 98-108.

Moorhead, G. \& Griffin, R. (2013). Perilaku Organisasi Manajemen Sumber Daya Manusia dan Organisasi. Jakarta: Salemba Empat.

Mustiningsih. (2013). Pengantar Kepemimpinan Pendidikan. Malang: Fakultas Ilmu Pendidikan Universitas Negeri Malang.

Robbin, S. \& Judge, T. A. (2007). Perilaku Organisasi: Organizational Behavior. Jakarta: Salemba Empat.

Siagian. S. 2004. Teori Motivasi dan Aplikasinya. Jakarta: Rineka Cipta.

Simbolon, H. (2015). Pengaruh Motivasi Terhadap Loyalitas Kerja Karyawan Bagian Marketing Pada Pt.Agung Automall Cabang Pekanbaru. Jurnal online mahasiswa Fakultas Ilmu Sosial dan Ilmu Politik Universitas Riau, 2(1)

Sisdawati, C. L. (2016). Analisis Motivasi yang Mempengaruhi Loyalitas Kerja Manajer di Kawasan Industri Terboyo Semarang (Tinjauan Berdasarkan Teori Kebutuhan Maslow). (Online), (http://repository.unika.ac.id/9189/), diakses pada 9 Mei 2018.

Sutisna. (2012). Perilaku Konsumen dan Komunikasi Pemasaran. Bandung: Remaja Rosdakarya.

Undang-Undang Nomor 20 Tahun 2003 tentang Sistem Pendidikan Nasional. 2013. Bandung: Citra Umbara. 